\title{
Description of the puparium of Cyphomyia aurifrons Wiedemann and Cyphomyia picta Schiner (Diptera, Stratiomyidae, Clitellariinae) from Ilha da Marambaia, Rio de Janeiro, Brazil
}

\author{
Roberto de Xerez ${ }^{1}$, Gustavo Glória Viana ${ }^{1}$ \& José Roberto Pujol-Luz ${ }^{2}$ \\ ${ }^{1}$ Departamento de Biologia Animal, Instituto de Biologia, Universidade Federal Rural do Rio de Janeiro. Rodovia BR 465, \\ Km 07, 23890-000 Seropédica, Rio de Janeiro, Brasil. E-mail: rdexerez@ufrrj.br; ggviana@ufrri.br \\ ${ }^{2}$ Departamento de Zoologia, Instituto de Biologia, Universidade de Brasília. 70910-900 Brasília, Distrito Federal, Brasil. \\ E-mail: jrpujol@unb.br
}

\begin{abstract}
The puparia of Cyphomyia aurifrons Wiedemann, 1830, and Cyphomyia picta Schiner, 1868 are described for the first time. The larvae were collected under the bark of fallen trees in a tropical rain forest at llha da Marambaia, State of Rio de Janeiro, Brazil, ( $23^{\circ} 04^{\prime} 15^{\prime \prime} \mathrm{S}, 43^{\circ} 53^{\prime} 59^{\prime \prime} \mathrm{W}$, sea level, approximately $\left.42 \mathrm{Km}^{2}\right)$. Some biological notes are also presented.
\end{abstract}

KEY WORDS. Soldier flies, taxonomy, tropical rain forest.

RESUMO. Os pupários de Cyphomyia aurifrons Wiedemann, 1830 e Cyphomyia picta Schiner, 1868 são descritos pela primeira vez. As larvas foram coletadas sob a casca de árvores caídas em uma floresta tropical situada na llha da

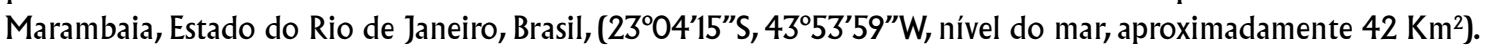
Notas biológicas são fornecidas.

PALAVRAS CHAVE. Floresta tropical, moscas soldado, taxonomia.

The Clitellariinae genus Cyphomyia Wiedemann, 1819, is widespread in the Neotropics, from Mexico to Argentina with 72 species (WoOdLey 2001). Thirty one species are known from Brazil (Woodley 2001) and from these only four species occur in Rio de Janeiro (Pujol-Luz 2002).

Wiedemann (1819) recognized Cyphomyia based on the following characters: face convex, eyes contiguous (rarely separated) in the males, broadly separated in the females, flagellum cylindrical, without a style, thorax rather elongated, scutellum rather large, trapezoidal, with two prominent spines set at the outer angles, abdomen circular oblong-ovate in outline, rather flattened, sometimes with pale markings but more often uniformly unicolorous, metallic black or blue, frequently ornamented with patches of apressed silvery pile.

Clitellarinae larvae from the Neotropics are poorly described. IIDE (1963a, b, 1967, 1968) (Cyphomyia leucocephala Hoffmansegg in Wiedemann (1830); Chordonota inermis Wiedemann, 1830; Cyphomyia souzalopesi Iide, 1967; Euryneura robusta Kertész, 1908, respectively) and Viana et al. (2003) (Auloceromyia vespiformis Lindner, 1969) furnished the last records for Neotropical larvae in this subfamily. Larvae of other three species of Clitellariinae were registered to the south of the United States (Mexico). James $(1957,1962)$ described the larva of Cyphomyia pilosissima Gerstaecker, 1857 and Dicyphoma schaefferi Coquillett, 1904, respectively and McFAdDEN (1967) described the larva of Cyphomyia marginata Loew, 1866.

Herein the puparia of Cyphomyia aurifrons Wiedmann, 1830, based on twelve puparia and Cyphomyia picta Schiner, 1868 , based on one puparium are described for the first time. The larval features studied in this work are the same used by VIANA et al. (2003).

Larvae of Cyphomyia aurifrons and Cyphomyia picta were collected under unidentified bark of fallen trees in a tropical

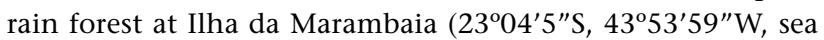
level), State of Rio de Janeiro, Brazil, outside and inside the forest behind a dam.

The larvae of C. aurifrons and C. picta were reared in laboratory as the methodology described in Pujol-Luz \& Xerez (1999) and VIANA et al. (2003). It seems that oviposition occurs in the moist substance, through crevices in the bark, because a large number of the smallest larvae of $C$. aurifrons and C. picta were found there.

Field and laboratory observations suggest that larvae of C. aurifrons and C. picta feed on microorganisms occurring in the moist areas beneath the bark of trees.

The adopted terminology follows James (1981) and RozkošNÝ \& KovaC (1994). The specimens upon which this study was based were deposited in the Coleção Entomológica Costa Lima (CECL), Universidade Federal Rural do Rio de Janeiro (UFRRJ), Instituto de Biologia, Seropédica, Brazil.

Revista Brasileira de Zoologia 21 (1): 79-83, março 2004 

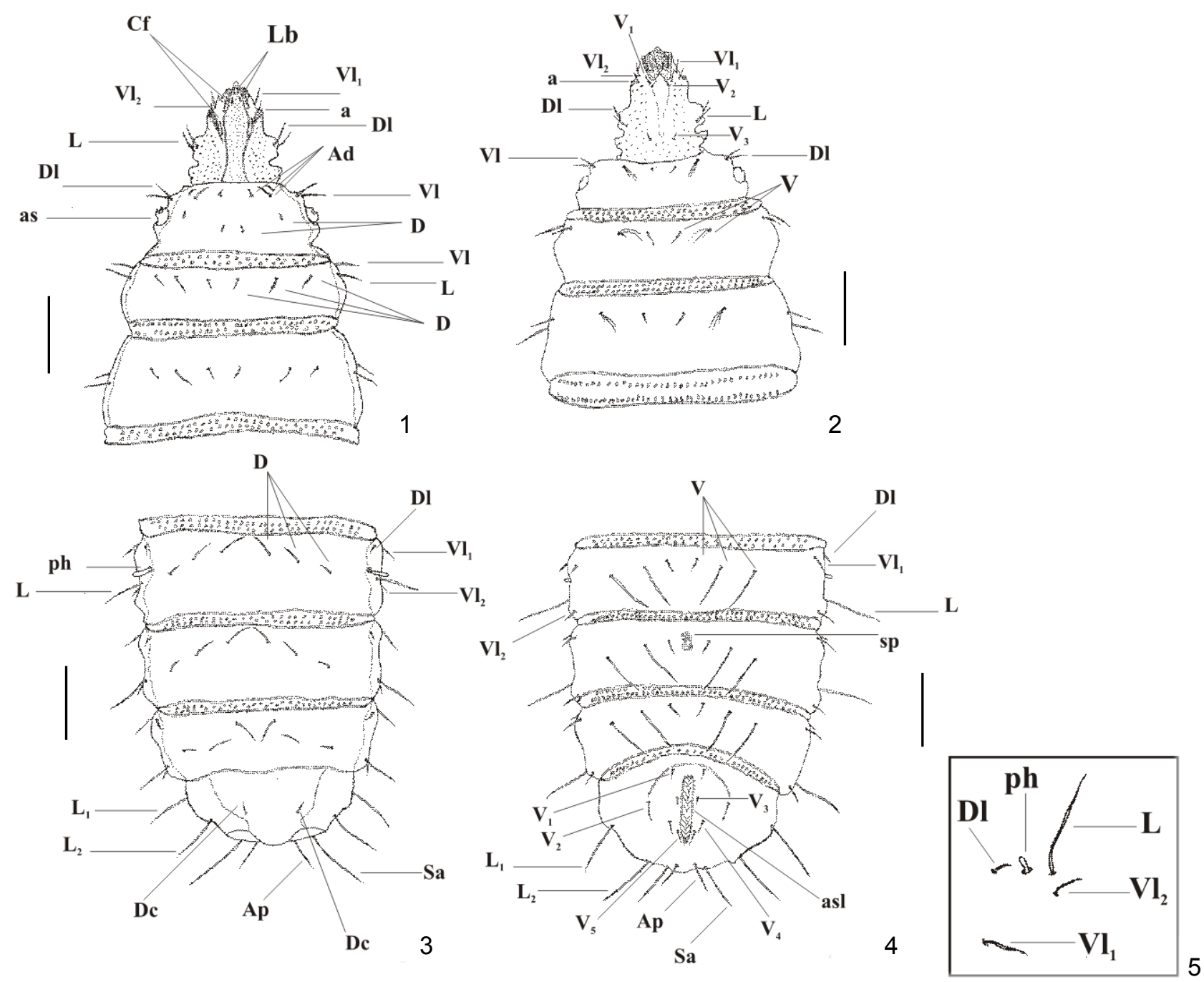

Figures 1-5. Cyphomyia aurifrons: (1) head and toracic segments, dorsal view, (2) head and toracic segments, ventral view, (3) $5^{\text {th }}$ to $8^{\text {th }}$ abdominals segments, dorsal view, (4) $5^{\text {th }}$ to $8^{\text {th }}$ abdominals segments, ventral view, (5) lateral view of $5^{\text {th }}$ abdominal segment. (a) Antenna, (Ad) anterodorsal seta, (Ap) apical seta, (as) anterior spiracle, (asl) anal slit, (Cf) clypeofrontal seta, (D) dorsal seta, (Dc) dorsocentral seta, (DI) dorsal seta, (L) lateral seta, (Lb) labral seta, (ph) pupal respiratory horn, (Sa) subapical seta, (sp) sternal patch, (V) ventral seta, $(\mathrm{Vl})$ ventrolateral seta. Scale $=1 \mathrm{~mm}$.

\section{Cyphomyia aurifrons Wiedemann, 1830} Figs 1-5

Cyphomyia aurifrons Wiedemann, 1830: 56 (original description); James, 1973: 25 (catalogue); Woodley, 2001: 159 (catalogue).

Distribution. Neotropical: Argentina, Brasil: Rio de Janeiro (new record), Ecuador.

Material examined. BraziL, Rio de Janeiro: Ilha da Marambaia, 17.II.1998, R. de Xerez leg., 12 puparia (emerged:
30.III.1998, 02.IV.1998, 01.IV.1998, 10.IV.1998, 15.IV.1998, 18.IV.1998, 21.IV.1998, 24.IV.1998, 05.V.1998, 09.V.1998, 16.V.1998 and 20.V.1998 - 11 females and 1 male).

Puparium. Length 13.0 to $15.0 \mathrm{~mm}$, dorsoventrally flattened, lateral margin of body segments strongly arched. Cuticle with the usual mosaic appearance, some cells forming characteristic patches and plaques on abdominal segments 6 and 8. Chromatic pattern yellowish brown, with some dark punctuations. As with other stratiomyids the puparium is developed from the last larval skin and retains many larval features.

Revista Brasileira de Zoologia 21 (1): 79-83, março 2004 
Head. Short, moderately flat; mandibular-maxillary complex with well-developed, cylindrical brushes almost as long as the labrum, in dorsal view; labrum triangular. Antenna short bisegmented, rising at the anterior part of head. Eyes prominent, rounded, arising at the posterior part of the head. Two pairs of clypeofrontal setae (Cf), one pair of dorsolateral setae (Dl) inserted above the eyes and one pair of lateral setae (L) inserted below eyes; two pairs of ventrolateral setae (Vl) and three pairs of ventral setae (V) (Figs 1-2).

Thorax. First segment shorter than the others. Spiracle (as) prominent in lateral view ornated by one dorsolateral setae (Dl) and one ventrolateral setae (Vl) (Figs 1-2). First segment with one row of three anterodorsal setae (Ad), inner and outer smaller and two pairs of dorsal setae (D) (Fig. 1), in ventral view two pairs of ventral setae $(\mathrm{V})$, outer trifurcated. Second and third segments with three pairs of dorsal setae (D), inner and outer smaller, in ventral view like first segment. Laterally both with one pair of lateral setae (L) and one pair of ventrolateral setae (Vl) (Fig. 1).

Abdomen. Segments 1-7 with the same shape, in dorsal view (Fig. 3) with three pairs of dorsal setae, in decrease size from the inner to outer one, in ventral view (Fig. 4) three pairs of ventral setae, the inner shorter, the others at same size. In lateral view (Fig. 5) one pair of dorsolateral setae, one pair of lateral setae and two pairs of ventrolateral setae anterior longer than posterior. A conspicuous pupal respiratory horn (ph) in segments 2-5 (Fig. 5); ventromedial line of segment 6 with an elliptical sternal patch (sp) with a little constriction in the middle (Fig. 4). Segment 8 rounded with one pair of dorsocentral setae (Dc) (Fig. 3), in ventral view five pairs of ventral setae; in lateral view two pair of lateral setae (L), one pair of apical setae (Ap) and one pair of subapical setae (Sa) (Fig. 4).

\section{Cyphomyia picta Schiner, 1868 Figs 6-10}

Cyphomyia picta Schiner, 1868: 53 (original description); James, 1973: 27 (catalogue); Woodley, 2001: 162 (catalogue).

Distribution. Neotropical: Brazil, Rio de Janeiro (new record), Costa Rica, Ecuador, Panama.

Material examined. BrazIL, Rio de Janeiro: Ilha da Marambaia, 17.II.1998, R. de Xerez leg., 1 puparium (emerged 26.IV. 1998 - 1 female).

Puparium. Length $16.0 \mathrm{~mm}$, dorsoventrally flattened, lateral margins of body segments strongly arched. Cuticle with usual mosaic appearance, some cells forming characteristic patches and plaques on abdominal segments 6 and 8. Chromatic pattern yellowish brown. As with other stratiomyids the puparium is developed from the last larval skin and retains many larval features.

Head, Elongated and projected to the front, labrum triangular. Antenna (a) short bisegmented, rising at the anterior part of head with a fast lump of both the sides (Fig. 6). Eyes prominent with a fast circumvallation in the medium region. Two pairs of clypeofrontal setae (Cf), one pair of dorsolateral setae (Dl) inserted above the eyes and one pair of lateral setae (L) inserted below eyes; three pairs of ventrolateral ( $\mathrm{Vl}$ ) and ventral setae (V) (Fig 6-7).

Thorax. First segment shorter than others. Spiracle (as) prominent, in lateral view rounded by one dorsolateral setae (Dl) and one ventrolateral seta (Vl) (Figs 6-7). First segment with one row of three pairs of anterodorsal setae (Ad) outer smaller and two pairs of dorsal setae (D) (Fig. 6), in ventral view two pairs of ventral setae (V), outer trifurcated (Fig. 7). Second and third segments with three pairs of dorsal setae (D), outer smaller, in ventral view similar to the first segment. Laterally both with one pair of lateral setae (L) and one pair of ventrolateral setae (Vl) (Figs 6-7).

Abdomen. Segments 1-7 with the same shape, in dorsal view three pairs of dorsal setae (D), the inner bigger than others and its point of insertion is located more previously in relation to the others two pairs, the outer smaller (Fig. 8), in ventral view three pairs of ventral setae $(V)$, the inner shorter than others (Fig. 9). In lateral view one pair of dorsolateral setae, one pair of lateral setae and two pairs of ventrolateral setae (Fig. 10) Pupal respiratory horn (ph) short, in segments $2-5$. Ventromedial line of segment 6 with a circular sternal patch (sp) (Fig. 9). Segment 8 rounded with one pair of dorsocentral setae (Dc), in ventral view five pairs of ventral setae (V); in lateral view two pair of lateral setae (L), one pair of apical setae (Ap) and one pair of subapical setae (Sa) (Fig. 9).

Comments. The larva of $C$. pilosissima was described by JAMES (1957) in details. Differs from C. aurifrons and C. picta by the position and number of the anterodorsal setae and by the absence of dorsolateral setae in the first toracic segment. It also presents two bulbous tubercles behind each eye, absents in C. aurifrons and C. picta. The larva of C. pilosissima is also longer than the larva of $C$. aurifrons and C. picta with the total length reaching more than $18 \mathrm{~mm}$.

The description of the larva of C. marginata made by McFadDEn (1967) is very incomplete. He only illustrates the first abdominal segment. Differs from C. picta by presenting the dorsal (Dl) and lateral (L) setae shorter and from C. aurifrons by presenting the medium dorsal setae of the first abdominal segment shorter, as well as the pupal horns not so visible. It also differs regarding to the total length of the larva, that is longer $(20,1 \mathrm{~mm})$ than those of the two other species (13$15 \mathrm{~mm}$ and $16 \mathrm{~mm}$ respectively).

IIDE (1963a) described in details the larva of C. leucocephala. It differs from those $C$. aurifrons and C. picta by presenting a single pair of dorsal setae in the first toracic segment and external ventral setae bifurcated (trifurcated in the two other species).

IIDE (1967) described in details three larval stages of $C$. souzalopesi. They differs from those of $C$. aurifrons and C. picta by presenting in the last larval stage all lateral, dorsolateral and ventrolateral plume-like setae. 

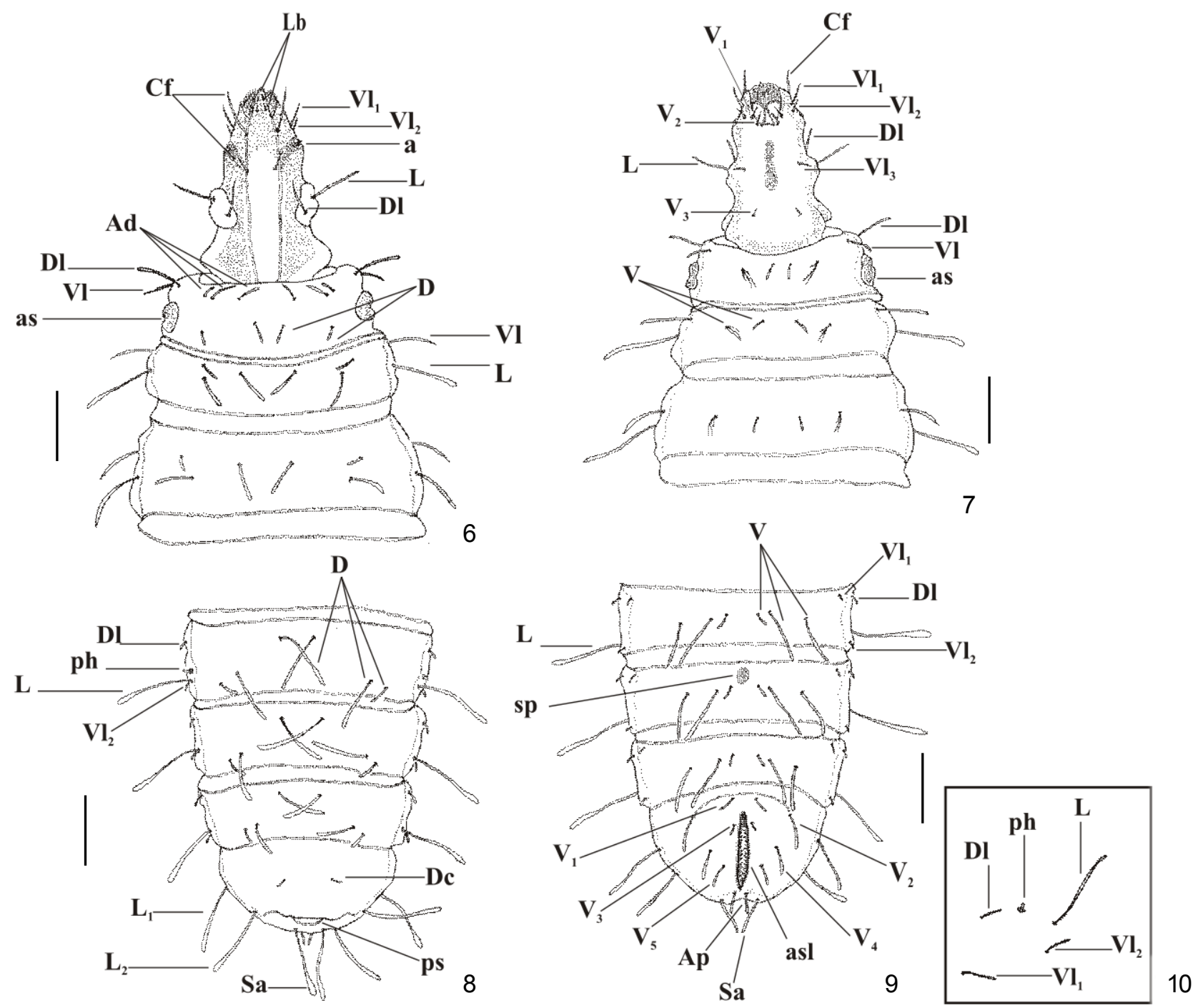

Figures 6-10. Cyphomyia picta: (1) head and toracic segments, dorsal view, (2) Head and toracic segments, ventral view, (3) $5^{\text {th }}$ to $8^{\text {th }}$ abdominals segments, dorsal view, (4) $5^{\text {th }}$ to $8^{\text {th }}$ abdominals segments, ventral view, (5) lateral view of $5^{\text {th }}$ abdominal segment. (a) Antenna, (Ad) anterodorsal seta, (Ap) apical seta, (as) anterior spiracle, (asl) anal slit, (Cf) clypeofrontal seta, (D) dorsal seta, (Dc) dorsocentral seta, (DI) dorsal seta, (L) lateral seta, (Lb) labral seta, (ph) pupal respiratory horn, (Sa) subapical seta, (sp) sternal patch, (V) ventral seta, $(\mathrm{Vl})$ ventrolateral seta. Scale $=1 \mathrm{~mm}$.

\section{ACKNOWLEDGMENT}

To Commander Capitão de Mar-e-Guerra(FN) Nilton Moreira Salgado (Centro de Adestramento da Ilha da Marambaia, CADIM) for the logistics for field work. To Conselho Nacional de Desenvolvimento Científico e Tecnológico, CNPq, grant \# 300265/96-4 (JRPL) and Programa Institucional de Bolsas de Iniciação Científica, PAPED-UFRRJ (GGV). To Drs Fabio Bettini Pitombo and Hélio Ricardo da Silva for kindly revising the manuscript.

\section{REFERENCES}

IIDE, P. 1963a. Contibuição ao conhecimento do gênero Cyphomyia Wiedemann, 1819 (Diptera, Stratiomyidae). Memórias do Instituto Oswaldo Cruz, Rio de Janeiro, 61 (1): 25-39.

1963b. Contribuição ao conhecimento do gênero Chordonota Gerstaecker, 1857 (Diptera, Stratiomyidae). Memórias do Instituto Oswaldo Cruz, Rio de Janeiro, 61 (3): 401-409. 
1967. Estudo sobre uma nova espécie amazônica do gênero Cyphomyia Wiedemann (Diptera, Stratiomyidae). Atas do Simpósio sobre a Biota Amazônica (Zoologia) 5, p. 225-238.

1968. Contribuição ao conhecimento das espécies brasileiras do gênero "Euryneura" Schiner, 1867 (Diptera, Stratiomyidae). Revista Brasileira de Biologia, Rio de Janeiro, 28 (3): 251-272.

James, M.T. 1957. The larva of Cyphomyia (Diptera, Stratiomyidae) and its significance in classification. Annals of the Entomological Society of America, College Park, 50: 639-641.

- 1962. The genus Dicyphoma James (Diptera: Stratiomyidae). Annals of the Entomological Society of America, College Park, 55: 15-20. . 1973. A catalogue of the Diptera of the Americas south of the United States. 26. Family Stratiomyidae. Museu de Zoologia da Universidade de São Paulo, São Paulo, $95 \mathrm{p}$.

. 1981. Stratiomyidae. p. 497-511. In J.F. McAlpine; B.V. Peterson; G.E. Shewell; H.J. Teskey; J.R. Vockeroth \& D.M. Wood. (Eds). Manual of Nearctic Diptera. Ottawa, Agriculture Canada, vol. 1, I-VI + 674 .

McFadden, M.W. 1967. Soldier Fly larvae in America North of Mexico. Proceedings of the United States National Museum, Washigton, D.C., 121 (3569): 1-72.

Pujol-Luz, J.R. \& R. DE Xerez 1999. The larva of Chalcidomorphina aurata Enderlein 1914 (Diptera: Stratiomyidae) from "Ilha da Marambaia", Rio de Janeiro, Brasil. Proceedings of the Entomological Society of Washington, Washingon, D.C., 101 (2): 295-299.

Pujol-Luz, J.R. 2002. Fauna Fluminensis - Stratiomyidade. On line at: http://www.unb.br/ib/zoo/docente/jrpujol/ Stratio_web1.html. Captured 11/III/2003.

RozkošnÝ, R. \& D. KovaC 1994. Adults and larvae of two Ptecticus Loew from Peninsular Malaysia (Diptera, Stratiomyidae). Tijdschrift voor Entomologie, Amsterdam, 137: 75-86.

Schiner, J.R. 1868. Diptera. In: Reise der österreichischen Fregatte Novara un die Erde in den Jahren 1857, 1858, 1859 , unter Befehlen des Commodore B. von WüllerstorfUrbair. Zoologischer Theil 2,1 (B). Kaiserlich-königlichen Hof-und Staatsdruckeri in Commission bei Karl Gerold's Sohn, Wien. I-VI, 1-388.

Viana, G.G., J.R. Pujol-Luz \& R de Xerez. 2003. Descrição da larva e do pupário de Auloceromyia vespiformis Lindner (Diptera: Stratiomyidae, Clitellariinae). Neotropical Entomology, São Paulo, 32 (1): 69-74.

Wiedmann, C.R.W. 1819. Brasilianische Zweiflüger. Zoologisches Magazin 1 (3): 40-56. . 1830. Aussereuropäische zweiflügelige Insekten. Zweiter Theil. Schulzischen Buchhandlung, Hamm. I-XII, 1-684.

Woodley, N.E. 2001. A world catalog of the Stratiomyidae (Insecta: Diptera). Myia, Washington, D.C., 11: 1-473.

Received in 08.VIII.2003; accepted in 22.I.2004. 